\title{
Store blødninger vanligst ved akutt keisersnitt
}

\section{Moderate og store blødninger skjer oftere ved akutt keisersnitt enn der inngrepet er planlagt. Det viser en stor norsk studie.}

Indikasjoner og medisinske forhold er ofte svært forskjellige ved planlagt og ved akutt keisersnitt. I studier om forekomst og risikofaktorer for blødninger ved keisersnitt er dette i liten grad tatt hensyn til.

I et tiårsmateriale fra Medisinsk fødsels-

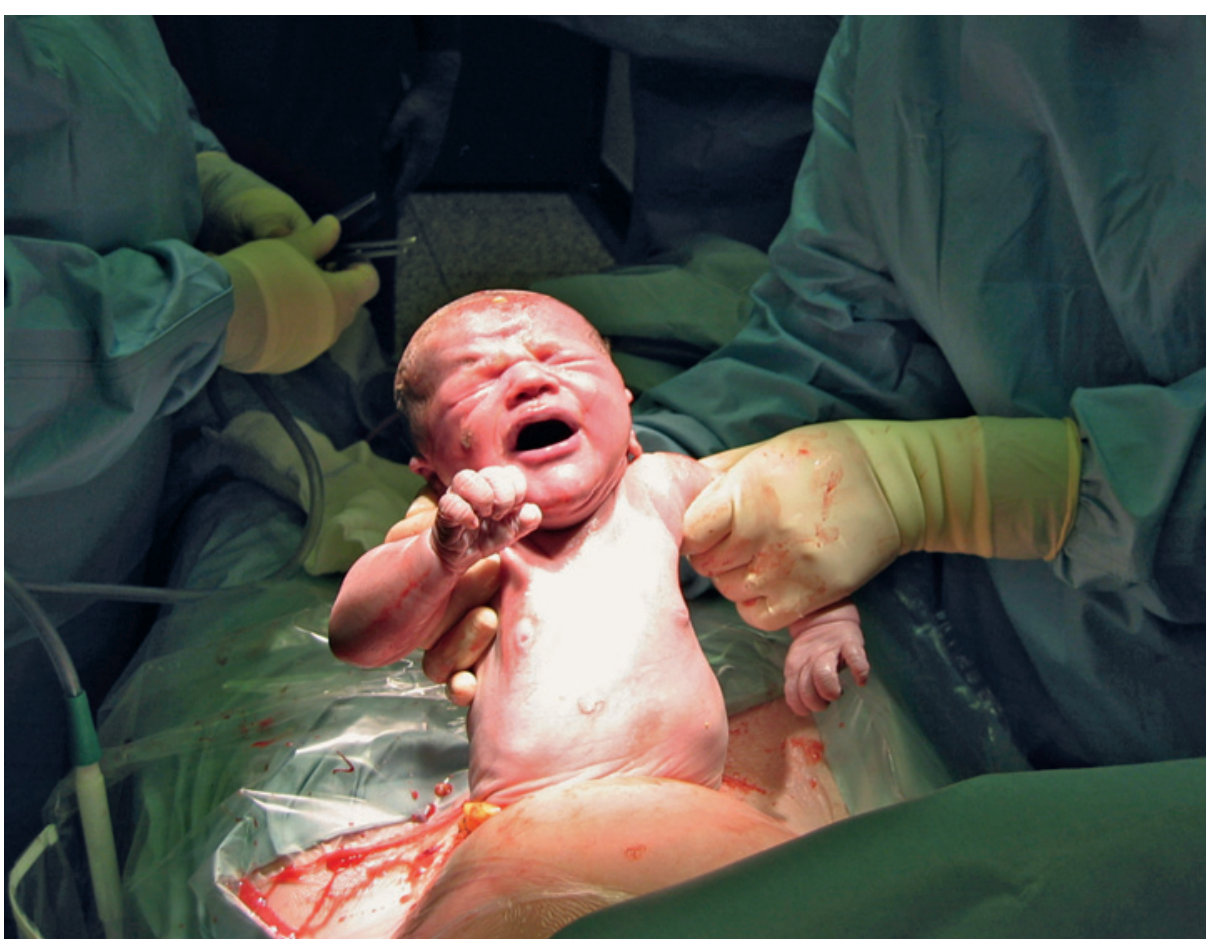

Illustrasjonsfoto Istockphoto

\section{Pytonolje er bra for musehjerter}

\section{Fettsyrer i postprandialt plasma fra pytonslange fører til gunstig fysiologisk hjertehypertrofi i slan- ger og mus.}

De fleste pattedyrmodeller for adaptiv gunstig hjertehypertrofi viser en moderat hjertehypertrofi på $10-20 \%$ etter flere uker med trening. Hos pytonslanger øker hjertemassen med $40 \%$ innen $2-3$ dager etter et stort måltid. Nå har amerikanske forskere studert de molekylære mekanismene bak denne ekstreme veksten for å kunne anvende kunnskapen på mennesker (1).

Forskerne fant ut at økningen i hjertemasse ikke var et resultat av celleproliferasjon, men av cellehypertrofi med aktivering av fysiologiske signalveier. Pytonhjertet akku- register fant vi at forekomsten av moderate blødninger (500-1 $500 \mathrm{ml})$ og store blødninger $(>1500 \mathrm{ml})$ er høyere ved akutt keisersnitt enn ved planlagt keisersnitt (1). Felles risikofaktorer, slik som tvillinger, tverrleie, placenta previa og store barn, kan forklares med tekniske vanskeligheter under operasjonen. Narkose ga økt risiko for store blødninger både ved planlagt og ved akutt keisersnitt uten at vi har noen god forklaring. Flere forhold som ga store blødninger ved akutte keisersnitt, slik som induksjon og manglende fremgang, kan forklares med uterusatoni.

Det store datasettet ga muligheter for å analysere samspill mellom flere faktorer. Induksjon av fødsel med normal fremgang og blødningsepisoder uten fall i hemoglobinnivå påvirket ikke blødningsrisikoen. Mange kvinner med store blødninger hadde ingen klar risikoprofil.

Til tross for flere signifikante funn er mange av risikoestimatene lave. Dessuten er forekomsten av hver enkelt risikofaktor liten. Det kan derfor være vanskelig å forebygge blødninger ved keisersnitt. Økt oppmerksomhet mot problemet, høy kirurgisk kompetanse ved svangerskap med kjente risikofaktorer og mer bruk av spinalanestesi fremfor narkose kan tenkes å redusere blødningsforekomsten. Siden mange av risikofaktorene for moderate og store blødninger er like, vil det å forebygge moderate blødninger også ha betydning for forekomsten av større.

\section{Finn Egil Skjeldestad \\ eskjelde@online.no \\ Avdeling for klinisk medisin \\ Universitetet i Troms $\varnothing$ \\ Litteratur \\ 1. Skjeldestad FE, Øian P. Blood loss after cesarean delivery: a registry-based study in Norway. 1999-2008. Am J Obstet Gynecol 2012; 206 76.e $1-7$.}

At det ble identifisert spesifikke fettsyrer mulerte ikke triglyserider eller fettsyrer, til tross for høye nivåer av sirkulerende lipider etter måltidene. Derimot ble det påvist en betydelig aktivering av transport og oksidasjon av fettsyrer, kombinert med økt ekspresjon av det kardioprotektive enzymet superoksiddismutase. Forskerne påviste en kombinasjon av fettsyrer i postprandialt pytonplasma som stimulerte til vekst av hjertet etter injeksjon i pyton og mus.

- Dette er en vel gjennomført studie om adaptiv gunstig hjertehypertrofi, sier overlege Thomas von Lueder ved Hjertemedisinsk avdeling, Akershus universitetssykehus. - Forskerne viste $i$ at slangemodellen ble de samme «gunstige» vekststimulerende signalveier fulgt som i klassiske treningsmodeller. Hypertrofien er reversibel og forsterker hjertets pumpekraft. i postprandialt pytonplasma som formidlet hjertehypertrofien, er svært interessant, sier von Leuder. - En tilsvarende syntetisk fettsyreblanding ga samme gunstige hypertrofi når den ble injisert $\mathrm{i}$ mus eller fastende pyton. Neste skritt vil være å teste om patologisk hypertrofi og annen remodellering, f.eks. ved eksperimentell hypertensjon eller hjerteinfarkt, kan påvirkes av disse fettsyrene på en gunstig måte, sier von Lueder.

\section{Trine B. Haugen}

trine.b.haugen@hf.hio.no

Tidsskriftet

\section{Litteratur}

1. Riquelme CA, Magida JA, Harrison BC et al. Fatty acids identified in the Burmese python promote beneficial cardiac growth. Science 2011; 334 528-31. 